\title{
Enhanced stratospheric water vapor over the summertime continental United States and the role of overshooting convection
}

\author{
Robert L. Herman ${ }^{1}$, Eric A. Ray ${ }^{2}$, Karen H. Rosenlof ${ }^{2}$, Kristopher M. Bedka ${ }^{3}$, Michael J. Schwartz ${ }^{1}$, \\ William G. Read ${ }^{1}$, Robert F. Troy ${ }^{1}$, Keith Chin ${ }^{1}$, Lance E. Christensen ${ }^{1}$, Dejian Fu ${ }^{1}$, Robert A. Stachnik ${ }^{1}$, \\ T. Paul Bui ${ }^{4}$, and Jonathan M. Dean-Day ${ }^{5}$ \\ ${ }^{1}$ Jet Propulsion Laboratory, California Institute of Technology, Pasadena, California, USA \\ ${ }^{2}$ National Oceanic and Atmospheric Administration (NOAA) Earth System Research Laboratory (ESRL) \\ Chemical Sciences Division, Boulder, Colorado, USA \\ ${ }^{3}$ NASA Langley Research Center, Hampton, Virginia, USA \\ ${ }^{4}$ NASA Ames Research Center, Moffett Field, California, USA \\ ${ }^{5}$ Bay Area Environmental Research Institute, Sonoma, California, USA
}

Correspondence to: Robert L. Herman (robert.l.herman@jpl.nasa.gov)

Received: 29 November 2016 - Discussion started: 19 December 2016

Revised: 9 April 2017 - Accepted: 10 April 2017 - Published: 17 May 2017

\begin{abstract}
The NASA ER-2 aircraft sampled the lower stratosphere over North America during the field mission for the NASA Studies of Emissions and Atmospheric Composition, Clouds and Climate Coupling by Regional Surveys $\left(\mathrm{SEAC}^{4} \mathrm{RS}\right)$. This study reports observations of convectively influenced air parcels with enhanced water vapor in the overworld stratosphere over the summertime continental United States and investigates three case studies in detail. Water vapor mixing ratios greater than $10 \mathrm{ppmv}$, which is much higher than the background 4 to $6 \mathrm{ppmv}$ of the overworld stratosphere, were measured by the JPL Laser Hygrometer (JLH Mark2) at altitudes between 16.0 and $17.5 \mathrm{~km}$ (potential temperatures of approximately 380 to $410 \mathrm{~K}$ ). Overshooting cloud tops (OTs) are identified from a SEAC ${ }^{4} \mathrm{RS}$ OT detection product based on satellite infrared window channel brightness temperature gradients. Through trajectory analysis, we make the connection between these in situ water measurements and OT. Back trajectory analysis ties enhanced water to OT 1 to 7 days prior to the intercept by the aircraft. The trajectory paths are dominated by the North American monsoon (NAM) anticyclonic circulation. This connection suggests that ice is convectively transported to the overworld stratosphere in OT events and subsequently sublimated; such events may irreversibly enhance stratospheric water vapor in the summer over Mexico and the United States. A regional
\end{abstract}

context is provided by water observations from the Aura Microwave Limb Sounder (MLS).

\section{Introduction}

Water plays a predominant role in the radiative balance of the Earth's atmosphere, both in the gas phase as the Earth's primary greenhouse gas and in condensed phases in cloud and aerosol. Despite its low abundance, upper tropospheric and lower stratospheric (UTLS) water vapor is critically important in controlling outgoing long-wave radiation; quantifying UTLS water vapor and its controlling processes is critical for climate characterization and prediction. Climate models are sensitive to changes in stratospheric water (Shindell, 2001) and clouds (Boucher et al., 2013). Increases in UTLS water are associated with warming at the surface on the decadal scale (Solomon et al., 2010). As the dominant source of hydroxyl radicals, UTLS water also plays an important role in the control of the UTLS ozone (Shindell, 2001; KirkDavidoff et al., 1999).

The overworld stratosphere, the altitude region with potential temperature $\theta$ greater than $380 \mathrm{~K}$ (Holton et al., 1995), is extremely dry, with typical mixing ratios of 3-6 parts per million by volume (ppmv). The importance of low temperatures at the tropical tropopause acting as a "cold trap" to 
prevent tropospheric water from entering the stratosphere has been recognized since Brewer (1949). Tropospheric air slowly ascends through the tropical tropopause layer (TTL) as part of the hemispheric-scale Brewer-Dobson circulation. In the TTL, air passes through extremely cold regions where water vapor condenses in situ to form cirrus ice, and then the cirrus slowly falls due to sedimentation (e.g., Jensen et al., 2005, 2013). Additional condensation and sedimentation are thought to be associated with convection and large-scale waves (e.g., Voemel et al., 2002). The amount of water that enters the stratosphere is largely a function of the coldest temperature that a parcel trajectory encounters. This typically occurs in the tropics, and the coldest temperature is typically near the tropical tropopause. The saturation mixing ratio at the cold point tropopause thereby sets the entry value of water vapor.

In contrast to water entry into the overworld stratosphere, water transport from the troposphere to the lowermost stratosphere $(350 \mathrm{~K}<\theta<380 \mathrm{~K}$ over summer CONUS) may occur through several different pathways. Poleward of the subtropical jet, water may be transported into the lowermost stratosphere through isentropic troposphere-stratosphere exchange (Holton et al., 1995) or through convective overshoot of the local tropopause (Dessler et al., 2007; Hanisco et al., 2007; Liu at el., 2008; Liu and Liu, 2016). Isentropic transport from the tropics is the dominant pathway for water into the lowermost stratosphere, with evidence from the seasonal cycle of lower stratospheric water (e.g., Flury et al., 2013). How important the sublimation of ice from convective overshoot is for hydrating the stratosphere is a topic of ongoing debate (e.g., Randel et al., 2015; Wang, 2003). Case studies have reported extreme events in which ice is transported to the overworld stratosphere and subsequently sublimates, but the amount of ice that is irreversibly injected into the stratosphere is poorly known. Airborne measurements have demonstrated that convective injection occurs both in the tropics (Webster and Heymsfield, 2003; Corti et al., 2008; Sayres et al., 2010; Sargent et al., 2014) and at mid-latitudes (Hanisco et al., 2007; Anderson et al., 2012). Ice injected directly into the stratosphere is unaffected by the cold trap in the vicinity of the tropopause (Ravishankara, 2012).

The subject of this paper is the role of convective overshooting tops in enhancing stratospheric water. Paraphrasing Bedka et al. (2010), a convective overshooting top (OT) is a protrusion above a cumulonimbus anvil caused by strong updrafts above the equilibrium level. Early observations of OT include photographs of OT in the stratosphere from a U-2 aircraft (Roach, 1967). Recent observations of elevated water mixing ratios in the summer overworld stratosphere by aircraft (Anderson et al., 2012) and the Aura Microwave Limb Sounder (MLS; Schwartz et al., 2013) suggest that ice injection into the overworld stratosphere by OT, while rare, occurs in three predominant regions during the summer season. These three regions are the Asian monsoon region, the South

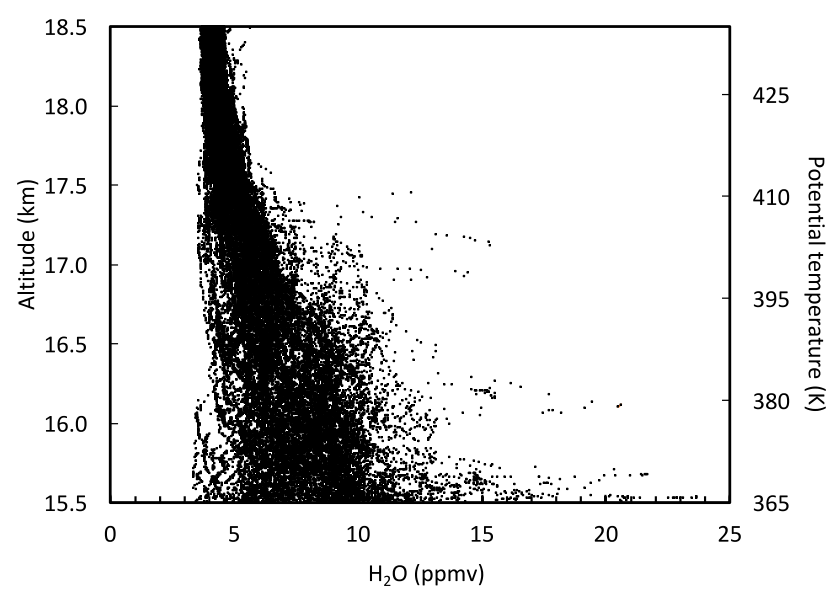

Figure 1. The JLH Mark2 stratospheric water vapor profiles from 23 aircraft flights during SEAC ${ }^{4} \mathrm{RS}$. This altitude range includes the overworld stratosphere (potential temperature greater than $380 \mathrm{~K}$ ) and lowermost stratosphere (tropopause to $380 \mathrm{~K}$ ). The majority of the observations have mixing ratios lower than $10 \mathrm{ppmv}$ in the lowermost stratosphere and lower than 6 ppmv in the overworld stratosphere. Enhanced water measurements are the extreme outliers with high water mixing ratios and a threshold value of the mean plus 2 standard deviations.

American continent and the focus of this study, the North American monsoon (NAM) region (Schwartz et al., 2013).

The NASA ER-2 aircraft sampled the summer stratospheric NAM region during the field mission for the NASA Studies of Emissions and Atmospheric Composition, Clouds and Climate Coupling by Regional Surveys (SEAC ${ }^{4} \mathrm{RS}$ ) (Toon et al., 2016). One of the primary goals of this multiaircraft mission was to address the following question: do deep convective cloud systems locally inject water vapor and other chemicals into the overworld stratosphere over the continental United States (CONUS)? It is challenging for spaceand ground-based techniques to detect enhanced water vapor injected into the stratosphere by OTs. Satellite measurements are limited by their horizontal and vertical resolution in detecting fine-scale three-dimensional variations in water vapor, while ground-based measurements are confined to sampling at fixed locations. In contrast, airborne in situ stratospheric measurements of water have an advantage because the aircraft can be routed to a specific location, altitude, date and time. Modelers can predict whether air parcels are likely to have convective influence, and aircraft flight paths are planned to intercept those air parcels. The purpose of this paper is to report three new case studies of enhanced water vapor in the overworld stratosphere during the NASA SEAC ${ }^{4} \mathrm{RS}$ field mission and to connect these observations to deep convective OT over the North American continent. 
Table 1. A summary of the enhanced water vapor measurements in the overworld stratosphere during SEAC ${ }^{4} \mathrm{RS}^{*}$. The dates are NASA ER-2 aircraft flight dates in day-month-year format, and the JLH Mark2 maximum water vapor mixing ratios (ppmv) are shown for potential temperatures greater than $400 \mathrm{~K}$ (left) and in the range of 380-400 K (right).

\begin{tabular}{lrrrrrr}
\hline Date & $\begin{array}{r}\text { Max. water } \\
(\mathrm{ppmv})\end{array}$ & $\begin{array}{r}\text { Potential temp. } \\
(\mathrm{K})\end{array}$ & $\begin{array}{r}\text { Altitude } \\
(\mathrm{km})\end{array}$ & $\begin{array}{r}\text { Max. water } \\
(\mathrm{ppmv})\end{array}$ & $\begin{array}{r}\text { Potential temp. } \\
(\mathrm{K})\end{array}$ & $\begin{array}{r}\text { Altitude } \\
(\mathrm{km})\end{array}$ \\
& Above 400 K & Above 400 K & Above 400 K & $380-400 \mathrm{~K}$ & $380-400 \mathrm{~K}$ & $380-400 \mathrm{~K}$ \\
\hline 8-Aug-2013 & 10.1 & 401.2 & 17.29 & 11.2 & 385.7 & 17.10 \\
12-Aug-2013 & 8.0 & 400.1 & 17.08 & 13.2 & 388.1 & 16.86 \\
14-Aug-2013 & 7.7 & 402.2 & 17.38 & 10.7 & 387.4 & 16.75 \\
16-Aug-2013 & 7.0 & 400.2 & 17.14 & 12.2 & 387.3 & 16.82 \\
27-Aug-2013 & 15.3 & 402.8 & 17.32 & 17.7 & 380.8 & 16.12 \\
30-Aug-2013 & 9.2 & 400.2 & 17.27 & 12.0 & 390.0 & 16.81 \\
2-Sep-2013 & 8.0 & 400.3 & 17.07 & 13.0 & 380.3 & 16.28 \\
4-Sep-2013 & 6.3 & 405.0 & 17.57 & 10.8 & 380.2 & 16.32 \\
6-Sep-2013 & 6.8 & 400.1 & 17.12 & 15.6 & 381.0 & 16.32 \\
11-Sep-2013 & 7.7 & 400.2 & 17.13 & 10.2 & 381.0 & 16.22 \\
13-Sep-2013 & 6.9 & 401.8 & 17.55 & 9.2 & 382.4 & 16.41 \\
\hline
\end{tabular}

* SEAC ${ }^{4} \mathrm{RS}$ is the Studies of Emissions and Atmospheric Composition, Clouds and Climate Coupling by Regional Surveys

\section{Observations}

\subsection{Aircraft}

The airborne in situ water vapor measurements reported here are from the Jet Propulsion Laboratory Laser Hygrometer Mark2 (JLH Mark2), a tunable laser spectrometer with an open-path cell external to the aircraft fuselage (May, 1998). Water vapor is reported at $1 \mathrm{~Hz}(10 \%$ accuracy), although the time response of the open-path cell is much faster than this because the instrument samples the free-stream airflow. This instrument has a redesigned optomechanical structure for greater optical stability and was first flown in this configuration on the NASA ER-2 high-altitude aircraft during the SEAC ${ }^{4} \mathrm{RS}$ field mission. Pressure and temperature, provided by the Meteorological Measurement System (MMS; Scott et al., 1990), are used in the data processing to calculate water vapor mixing ratios from spectra, as described in May (1998).

During SEAC ${ }^{4} \mathrm{RS}$, nine aircraft flights targeted air parcels with recent convective influence (see Table 3 of Toon et al., 2016). Figure 1 shows the combined vertical profiles of JLH Mark2 water vapor from all $23 \mathrm{SEAC}^{4} \mathrm{RS}$ flights. Outliers with high water vapor mixing ratios are the focus of this study. Enhanced water vapor was measured on 11 flights (Table 1). Here we define "enhanced water vapor" as mixing ratios greater than 2 standard deviations above the mean in situ measurement. For the overworld stratosphere in all 23 SEAC ${ }^{4} \mathrm{RS}$ flights, the mean $\mathrm{H}_{2} \mathrm{O}$ is $6.7 \pm 1.5 \mathrm{ppmv}$ at $380-400 \mathrm{~K}$ and $5.0 \pm 0.8 \mathrm{ppmv}$ at $400-420 \mathrm{~K}$ (Fig. 2). Thus, the threshold for enhanced water vapor is $9.7 \mathrm{ppmv}$ at 380 $400 \mathrm{~K}$ and $6.6 \mathrm{ppmv}$ at $400-420 \mathrm{~K}$. The majority of the measurements have background water mixing ratios characteristic of the overworld stratosphere, 4 to 6 ppmv. For the overworld stratosphere (potential temperature greater than $380 \mathrm{~K})$, Fig. 1 shows enhanced water vapor at potential temperatures up to approximately $410 \mathrm{~K}$ (17.5 km of altitude). We define the "enhanced water region" as the layer of the overworld stratosphere where these events have been observed at $380-410 \mathrm{~K}$ of potential temperature corresponding to $16-17.5 \mathrm{~km}$ of altitude. Enhanced water vapor measured in situ by both the JLH Mark2 instrument (Fig. 1) and the Harvard Water Vapor instrument (Smith et al., 2015) on the NASA ER-2 aircraft indicated that the aircraft intercepted convectively influenced air. Other tracers measured on the aircraft did not change significantly in these plumes. For the $\mathrm{SEAC}^{4} \mathrm{RS}$ flights, the agreement between these two water vapor instruments is within $\pm 10 \%$ for stratospheric water. This is consistent with the AquaVIT laboratory intercomparison (Fahey et al., 2014) and other aircraft field missions (e.g., Rollins et al., 2014). The largest enhancements were observed on three flights that are described in detail in Sect. 4.

\subsection{Aura MLS}

Aura MLS measures $~ 3500$ profiles each day of water vapor and other atmospheric species (Livesey et al., 2016). While the aircraft samples in situ water in a thin trajectory through the atmosphere, Aura MLS provides a larger-scale context. Expanding on the analysis of Schwartz et al. (2013), Aura MLS observations of stratospheric water vapor are presented here for the SEAC ${ }^{4} \mathrm{RS}$ time period in summer 2013. Aura MLS $\mathrm{H}_{2} \mathrm{O}$ has $0.4 \mathrm{ppmv}$ of precision at $100 \mathrm{hPa}$ for individual profile measurements with a spatial representativeness of $200 \mathrm{~km}$ along the line of sight (Schwartz et al., 2013). The results shown here use MLS version 4.2 data, but are not significantly different from the previous version 3.3. MLS observations over CONUS are at $\sim$ 14:10 local time (ascending 


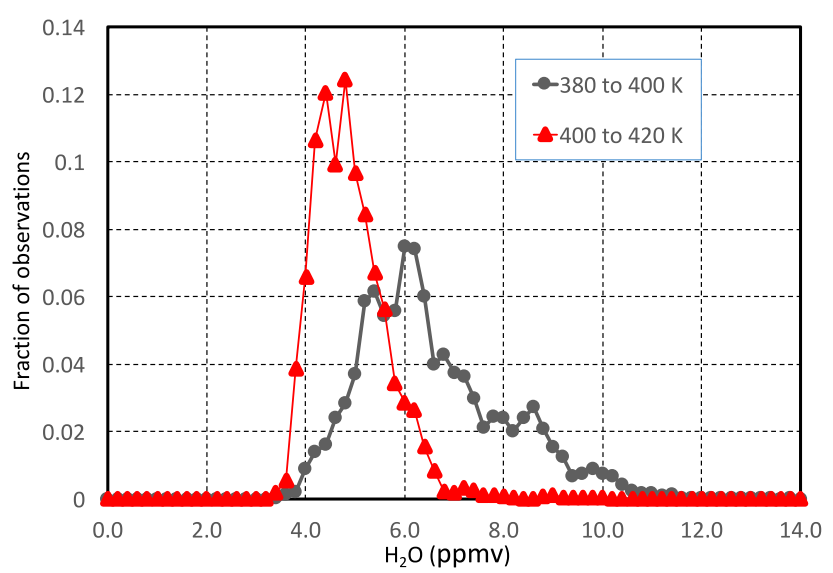

Figure 2. The distribution of JLH Mark2 water vapor in the overworld stratosphere for all flights in the SEAC ${ }^{4} \mathrm{RS}$ mission (summer 2013) plotted as a fraction of the observations in each potential temperature range. The first trace (black circles and line) is at potential temperatures of 380 to $400 \mathrm{~K}$, corresponding to approximately 16.8 to $17.4 \mathrm{~km}$ of altitude ( 99 to $90 \mathrm{hPa}$ ). The second trace (red triangles and line) is at potential temperatures of 400 to $420 \mathrm{~K}$, corresponding to approximately 17.4 to $18.0 \mathrm{~km}$ of altitude (90 to $80 \mathrm{hPa}$ ).

orbit) and $\sim$ 01:20 local time (descending orbit) with successive swaths separated by $\sim 1650 \mathrm{~km}$. The vertical resolution of the water vapor product is $\sim 3 \mathrm{~km}$ in the lower stratosphere (Livesey et al., 2016).

Aura MLS shows a seasonal maximum in water vapor over CONUS in July and August. The histogram of Aura MLS water vapor in Fig. 3 indicates that the July-August 2013 CONUS lower stratosphere was drier than the previous ninesummer MLS record (2004 to 2012). Nevertheless, enhanced lower stratospheric water vapor was observed by MLS in 2013 as a rare but detectable event. From the MLS histogram, the frequency of $100 \mathrm{hPa} \mathrm{H}_{2} \mathrm{O}>8 \mathrm{ppmv}$ was $0.9 \%$ of the observations in July-August 2013 in the blue shaded box. Figure 4 shows that, out of all MLS $100 \mathrm{hPa}$ water vapor retrievals over the 2-month period from July to August 2013, water greater than 8 ppmv was measured only nine times over North America (in the blue shaded box), three times near the west coast of Mexico and once over the Caribbean Sea.

\section{Analysis}

Here we briefly describe the analytical technique used to determine whether back trajectories from the aircraft location intersect OT as identified by a satellite OT data product.

\subsection{Detection of overshooting tops}

In order to link the stratospheric water vapor encountered by the aircraft to the storm systems from which they may have originated, it is necessary to have a comprehensive continental-scale catalog of deep convection. Geostationary

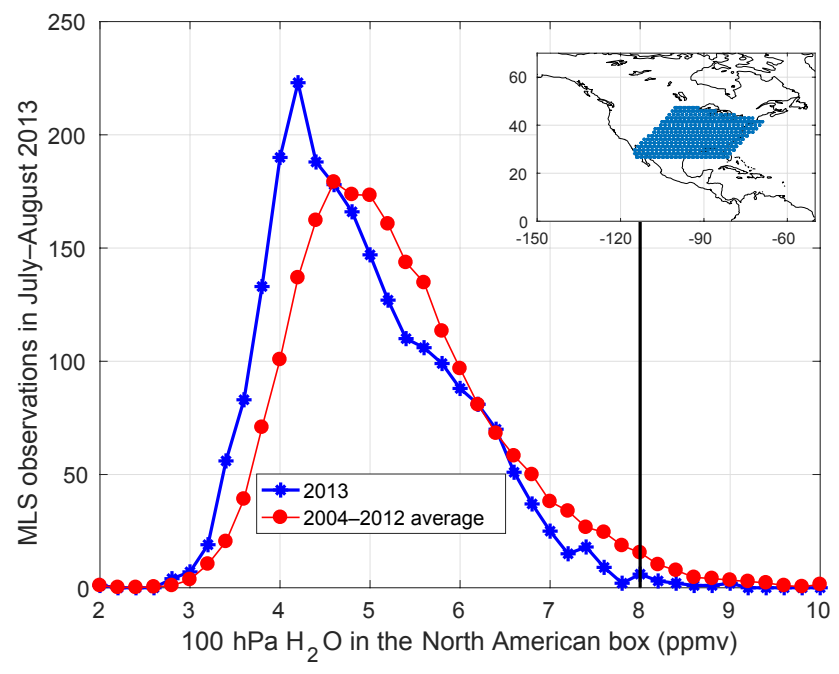

Figure 3. The distribution of Aura MLS v4.2 $100 \mathrm{hPa} \mathrm{H}_{2} \mathrm{O}$ over CONUS (blue shaded box in insert), corresponding to approximately $17 \mathrm{~km}$ of altitude. The two histograms for July-August 2013 (blue asterisks and trace) and the previous nine-summer MLS record, for July-August 2004 through 2012 (red circles and trace), indicate that 2013 was drier than average. The threshold for MLSdetected "enhanced water vapor" (thick black vertical line) is set at 8 ppmv, the same as in Schwartz et al. (2013), to exclude the larger population of measurements at 6 to 8 ppmv of water vapor that may have other sources.

Operational Environmental Satellite (GOES) infrared imagery is used to assemble a catalog of OTs throughout the US and offshore waters. This catalog was acquired from the NASA LaRC Airborne Science Data for Atmospheric Composition data archive (http://www-air.larc.nasa.gov/cgi-bin/ ArcView/seac4rs). Because OTs are correlated with storm intensity, the OT product was primarily developed to benefit the aviation community for more accurate turbulence prediction as well as the general public for earlier severe storm warnings. However, the product is also ideally suited for identifying storm systems that can moisten the stratosphere.

Infrared brightness temperatures are used to detect cloud top temperature anomalies within thunderstorm anvils. OT candidates are colder than the mean surrounding anvil, with the temperature difference indicative of both the strength of the convective updraft and the depth of penetration. For a description of the method, the reader is directed to Bedka et al. (2010). The horizontal spatial resolution of the OT product is dependent on the underlying satellite imagery resolution, i.e., the size of the GOES IR pixel, which is $7 \mathrm{~km}$ or less over the CONUS. Additional validation of OTs requires comparison with the Global Forecast System (GFS) Numerical Weather Prediction (NWP) model tropopause temperature. The maximum OT cloud height was derived based on knowledge of the (1) OT-anvil temperature difference, (2) the anvil cloud height based on a match of the anvil mean temperature near the OT and the GFS NWP temperature pro- 


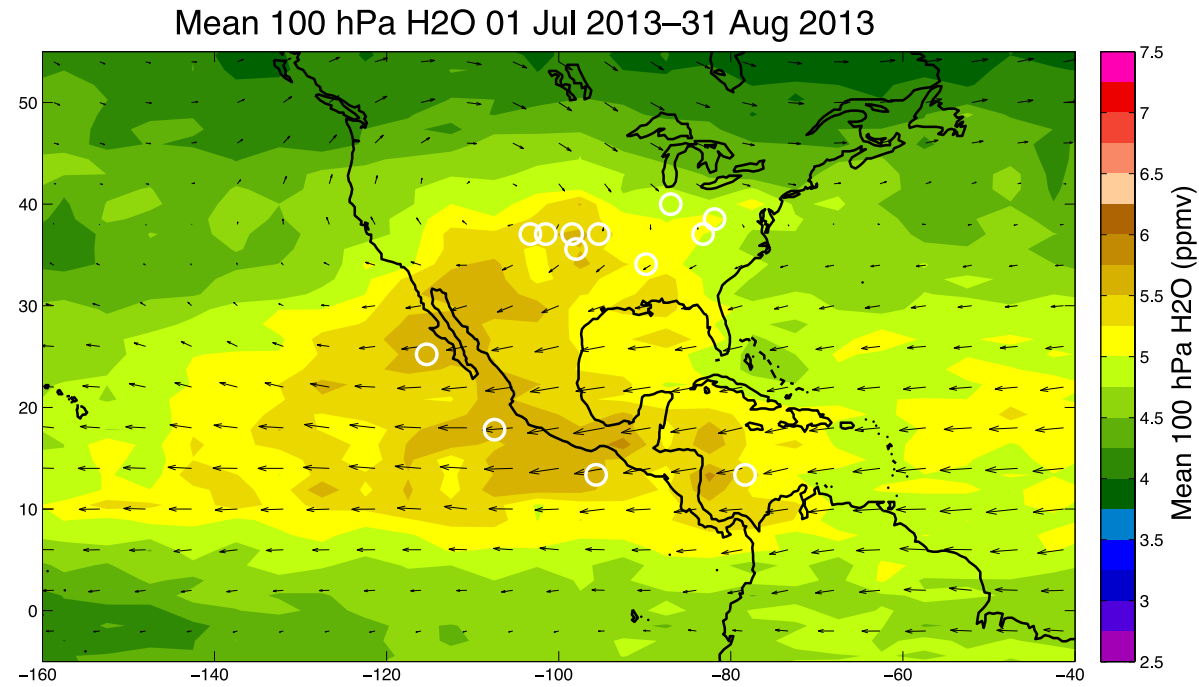

Figure 4. The 2-month mean map of Aura MLS v4.2 $100 \mathrm{hPa} \mathrm{H}_{2} \mathrm{O}$ (color scale), corresponding to approximately $17 \mathrm{~km}$ of altitude with superimposed MERRA horizontal winds (arrows) for July-August 2013 during the SEAC ${ }^{4} \mathrm{RS}$ time period. The MLS observations of $100 \mathrm{hPa}$ $\mathrm{H}_{2} \mathrm{O}$ greater than 8 ppmv in this 2-month period are shown by the white circles.

file and (3) a temperature lapse rate within the UTLS region based on a GOES-derived OT-anvil temperature difference and NASA CloudSat OT-anvil height difference for a sample of direct CloudSat OT overpasses (Griffin et al., 2016). Griffin et al. (2016) find that $75 \%$ of OT height retrievals are within $0.5 \mathrm{~km}$ of CloudSat OT height, so we conservatively estimate the accuracy of the OT altitude to $0.5 \mathrm{~km}$. For SEAC ${ }^{4} \mathrm{RS}$, every available GOES-East and GOES-West scan (typically $15 \mathrm{~min}$ resolution) was processed for the full duration of the mission, even for the non-flight days, yielding a detailed and comprehensive picture of the location, timing and depth of penetration of the convective storms over the entire CONUS. The output files include the OT coordinates, time, overshooting intensity in degrees $\mathrm{K}$, which is related to the temperature difference between the OT and the anvil, and an estimate of maximum cloud height for OT pixels in meters.

The ability of GOES-East and GOES-West to observe an OT depends on its lifetime. OTs are transient events with lifetimes typically less than $30 \mathrm{~min}$, but they can exceed 1 hour in well-organized storms such as mesoscale convective systems and supercell storms (Bedka et al., 2015; Solomon et al., 2016 and the references therein). Animations such as the following show the variability in OTs sampled by GOES at 1 min of resolution:

Infrared wavelength animation: http://cimss.ssec.wisc.edu/goes/srsor2015/

Visible wavelength animation:

http://cimss.ssec.wisc.edu/goes/blog/wp-content/uploads/

It is clear that some OTs are quite persistent and are both prominent and detectable in IR imagery, but the majority of OTs in these particular animations are short lived $(<10 \mathrm{~min})$. Within these OTs, strong convective updrafts can transport ice to $16-18 \mathrm{~km}$ of altitude where turbulent processes, such as gravity wave breaking, mix tropospheric and stratospheric air (e.g., Mullendore et al., 2009, 2005; Wang, 2003; Homeyer et al., 2017), enabling the detrainment of ice and stratospheric hydration.

Bedka et al. (2010) showed that the OT detection algorithm has a false positive rate of 4.2 to $38.8 \%$, depending on the size of the overshooting and algorithm settings. As noted above, OTs are transient and can evolve quite rapidly. The storm top characteristics and evolution we see in the GOES data featured in this paper only capture a subset of the storm lifetimes, even if we were to have a $100 \%$ OT detection rate, due to the $15 \mathrm{~min}$ resolution of the GOES imager. In addition, the relatively coarse GOES spatial resolution (up to $7 \mathrm{~km}$ over the northern latitudes of the US) can cause the Bedka et al. (2010) method to miss some small diameter and/or weak OT regions. We would be able to better map tracks of storm updrafts using data at $1 \mathrm{~min}$ of frequency like that shown by Bedka et al. (2015), but these data are not available over the broad geographic domains required for our analysis. Given uncertainties in back trajectories, GOES under-sampling and the fact that many OTs can be located in close proximity to one another, we are not able to make a direct connection between an individual OT and a stratospheric water vapor plume observed 1 day or more later. Rather, our analysis identifies a cluster of storms that are the best candidates for generating ice that sublimates into the enhanced water vapor plumes sampled by the ER-2.

\subsection{Back trajectory modeling}

Back trajectories were run from each flight profile for which enhanced water vapor was measured to determine whether 

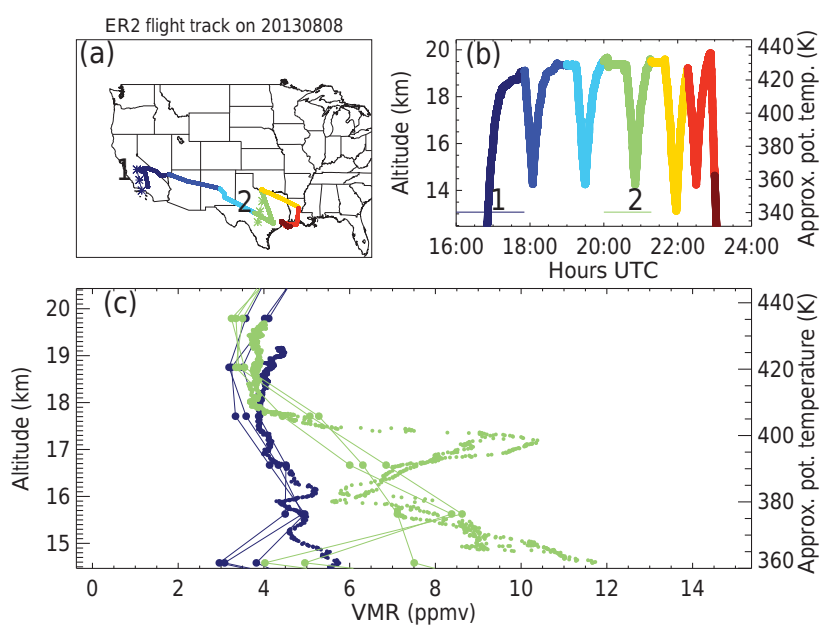

Figure 5. Map and profiles of aircraft and satellite water vapor on 8 August 2013 over California (number 1; shown in dark blue) and Texas (number 2; shown in green). (a) Map of the ER-2 aircraft flight track (solid colored trace) and nearly coincident Aura MLS geolocations (asterisks and lines). (b) ER-2 aircraft altitude profiles (solid colored trace) color coded by dives and MLS times (horizontal lines). (c) Vertical profiles of in situ water vapor measurements from JLH Mark2 (dots) and MLS retrievals of water vapor (circles and lines). Some measurements exceed the threshold for enhanced water vapor of 8 ppmv for Aura MLS (after Schwartz et al., 2013) and the campaign-wide mean plus 2 standard deviations for JLH Mark2, 9.7 ppmv at 380-400 K and $6.6 \mathrm{ppmv}$ at $400-420 \mathrm{~K}$.

the sampled air was convectively influenced. The trajectories were run with the FLEXPART model (Stohl et al., 2005) using NCEP Climate Forecast System version 2 (CFSv2) meteorology (Saha et al., 2014); the trajectory time step interval was $1 \mathrm{~h}$. Trajectories were initialized every second along the flight track profiles and run backward for 7 days. A sampled air parcel was determined to be convectively influenced if the back trajectory from that parcel intercepted an OT region. The tolerances for a trajectory to be considered to have intercepted an OT cloud were $\pm 0.25^{\circ}$ latitude and longitude, $\pm 3 \mathrm{~h}$ and $\pm 0.5 \mathrm{~km}$ in altitude. These tolerances were chosen primarily due to the resolution of the NCEP meteorology used to run the trajectories $\left(1^{\circ} \times 1^{\circ}\right)$ and based on personal communication with Leonard Pfister.

\section{Case studies}

In this section, we highlight three NASA ER-2 flights during which elevated stratospheric water was observed by JLH Mark2. These dates are 8, 16 and 27 August 2013. Similar results are seen from other hygrometers on the NASA ER-2 aircraft (Smith et al., 2015). For each of these ER-2 flights, the back trajectories are presented along with the intersection of coincident OT. The cases are described below.

\subsection{First case: 8 August 2013}

Figure 5 shows the details of the 8 August 2013 ER-2 aircraft flight. This flight was the transit flight from Palmdale, California $\left(34.6^{\circ} \mathrm{N}, 118.1^{\circ} \mathrm{W}\right)$, to Ellington Field in Houston, Texas $\left(29.6^{\circ} \mathrm{N}, 95.2^{\circ} \mathrm{W}\right)$. In addition to sending the NASA ER-2 aircraft to the destination base, the scientific goal of this flight was to create five profiles for the North American monsoon region plus the aircraft ascent and final descent. This flight shows a dramatic transition (from west to east) of background stratospheric water to enhanced water. In the lowermost stratosphere $(350 \mathrm{~K}<\theta<380 \mathrm{~K})$, water can be highly variable, but at $90 \mathrm{hPa}$ it is generally unusual to observe water vapor greater than 6 ppmv. As shown in Fig. 5c, there is a gradient in water vapor from west to east: 4.0 to $4.4 \mathrm{ppmv}$ at $90 \mathrm{hPa}(17 \mathrm{~km})$ over the west coast of CONUS (black and blue points) and greater than $10 \mathrm{ppmv}$ at $90 \mathrm{hPa}$ over Texas (green points). Simultaneous Aura MLS retrievals also demonstrate a west-to-east water vapor gradient on this day (lines and filled circles in Fig. 5c). Both JLH Mark2 and Aura MLS water vapor exceed the thresholds for enhanced water vapor.

An analysis of the 8 August 2013 case is shown in Fig. 6. For clarity, only some example trajectories (a subset of our analysis) are shown. These are displayed as thin blue traces in panels (b) and (c). The intersections of the example trajectories with coincident OT are shown as red squares in panels (b) and (c). All overshooting convective tops within $\pm 3 \mathrm{~h}$ of the red squares are shown by the green symbols in panels (b) and (c). Back trajectories from the flight track follow the anticyclonic NAM circulation over Western Mexico, the Great Plains and the Mississippi Valley (Fig. 6b). Every one of the example back trajectories intersects OT, as shown by the red symbols in Fig. 6b. For this flight, coincidences with overshooting convection are dominated by overshooting clouds over the Mississippi Valley and the Great Plains. All overshooting convections within the tolerances prescribed (see Sect. 3.2) for the back trajectories are shown by the green symbols in Figs. $6 \mathrm{~b}$ and $5 \mathrm{c}$. Figure $6 \mathrm{c}$ demonstrates the range of altitudes reached by the coincident overshooting convection and how many convective overshooting cells were coincident. The high resolution of the convective overshooting data meant that there could be multiple coincident convective overshooting cells for a single location on a back trajectory. It is significant that some of the green overshooting cells are higher altitude than the red coincident points, suggesting that overshooting air parcels descended slightly before mixing with the surrounding air. Figure $6 \mathrm{~d}$ indicates that the source of the enhanced water was dominated by overshooting clouds within 7 days prior to intercept by the aircraft.

\subsection{Second case: 16 August 2013}

The NASA ER-2 flight on 16 August 2013 was designed to survey the North American monsoon in a triangular flight 

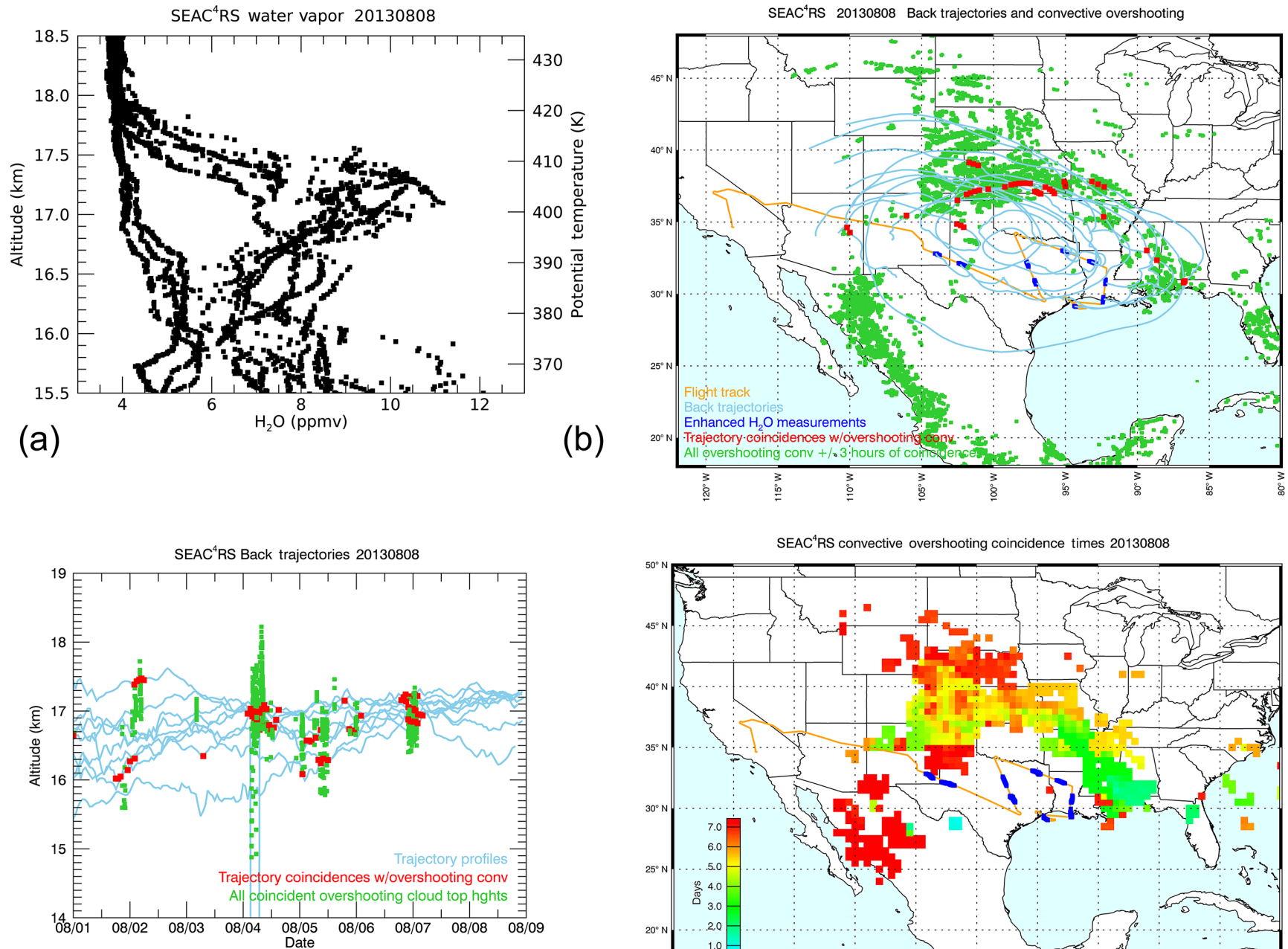

(c)

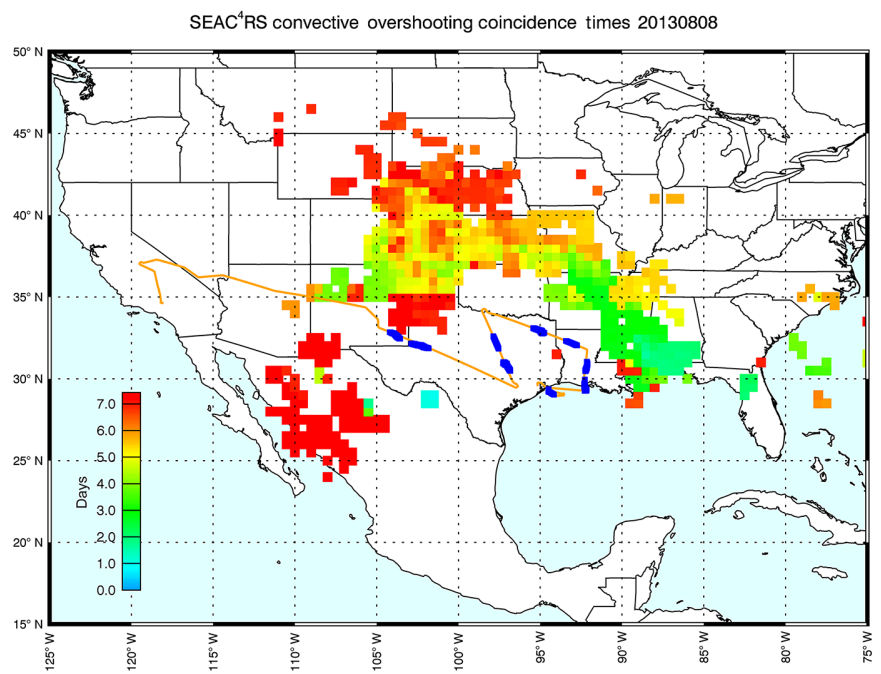

Figure 6. An analysis of the 8 August 2013 NASA ER-2 aircraft flight. (a) Vertical profiles of JLH Mark2 in situ $\mathrm{H}_{2} \mathrm{O}$. Back trajectories were initialized from all aircraft water measurements at 16 to $17.5 \mathrm{~km}$ of altitude. (b) Example back trajectories (thin blue traces) and coincident overshooting convection (red). Along the NASA ER-2 flight track (orange line), enhanced water vapor was measured (thick blue lines). This figure identifies where trajectories and OT are coincident (red squares) within the tolerances prescribed in Sect. 3.2. The green markers are overshooting convective tops within $\pm 3 \mathrm{~h}$ of the red squares to indicate the main regions of convective overshooting during the 7 days prior to the ER-2 flight and which of those regions appeared to contribute most to the water vapor enhancement measured on the flight. (c) Altitude plot of example back trajectories showing coincident overshooting (red squares). The green markers are overshooting convective tops within $\pm 3 \mathrm{~h}$ of the red squares. The high resolution of the convective overshooting data meant that there could be multiple coincident convective overshooting cells for a single location on a back trajectory. (d) Days between OT and intercept by the aircraft on 8 August 2013 .

path from Houston, Texas to the Imperial Valley in Southern California, to southeastern Colorado and back to Texas. The NASA ER-2 aircraft performed six dives, encountering enhanced stratospheric water at 16 to $17 \mathrm{~km}$ of altitude (Fig. 7a). As shown in Fig. 7b, back trajectories intersect overshooting tops over the South Central US (Texas, Oklahoma and Arkansas) and also over the Sierra Madre Occidental mountain range on the west coast of Mexico. This case is an example of the classic North American monsoon circulation with a moisture source over the Sierra Madre Oc- cidental (Adams and Comrie, 1997), in which air parcels are transported from OT in Mexico around the anticyclone to the CONUS (Fig. 7b). The altitude range of the convective overshoot is typically 16 to $17 \mathrm{~km}$, as shown in Fig. 7c. The time between OT and intercept by the aircraft ranges from 2 to 7 days (Fig. $7 d$ ).

\subsection{Third case: 27 August 2013}

The 27 August 2013 flight performed six dives to sample the North American monsoon. Stratospheric water was enhanced 


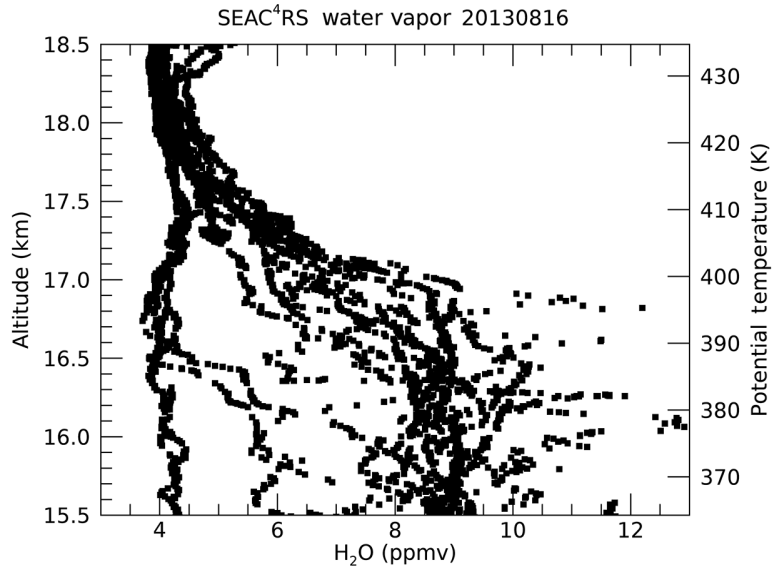

(a)

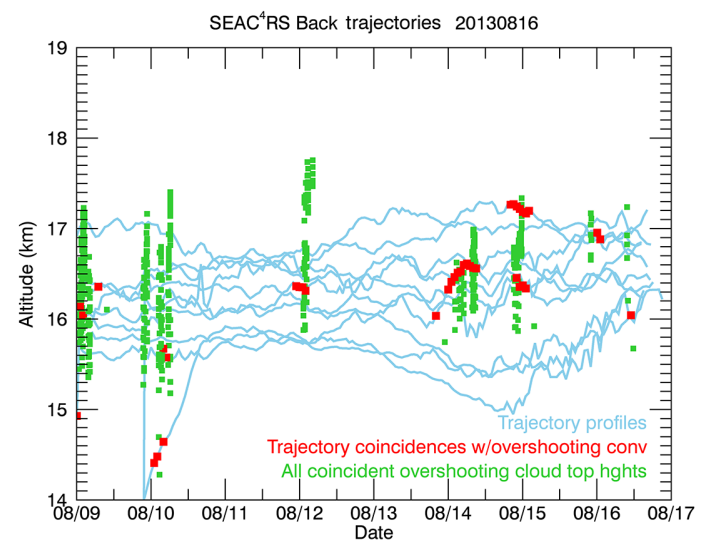

(c)

(d)
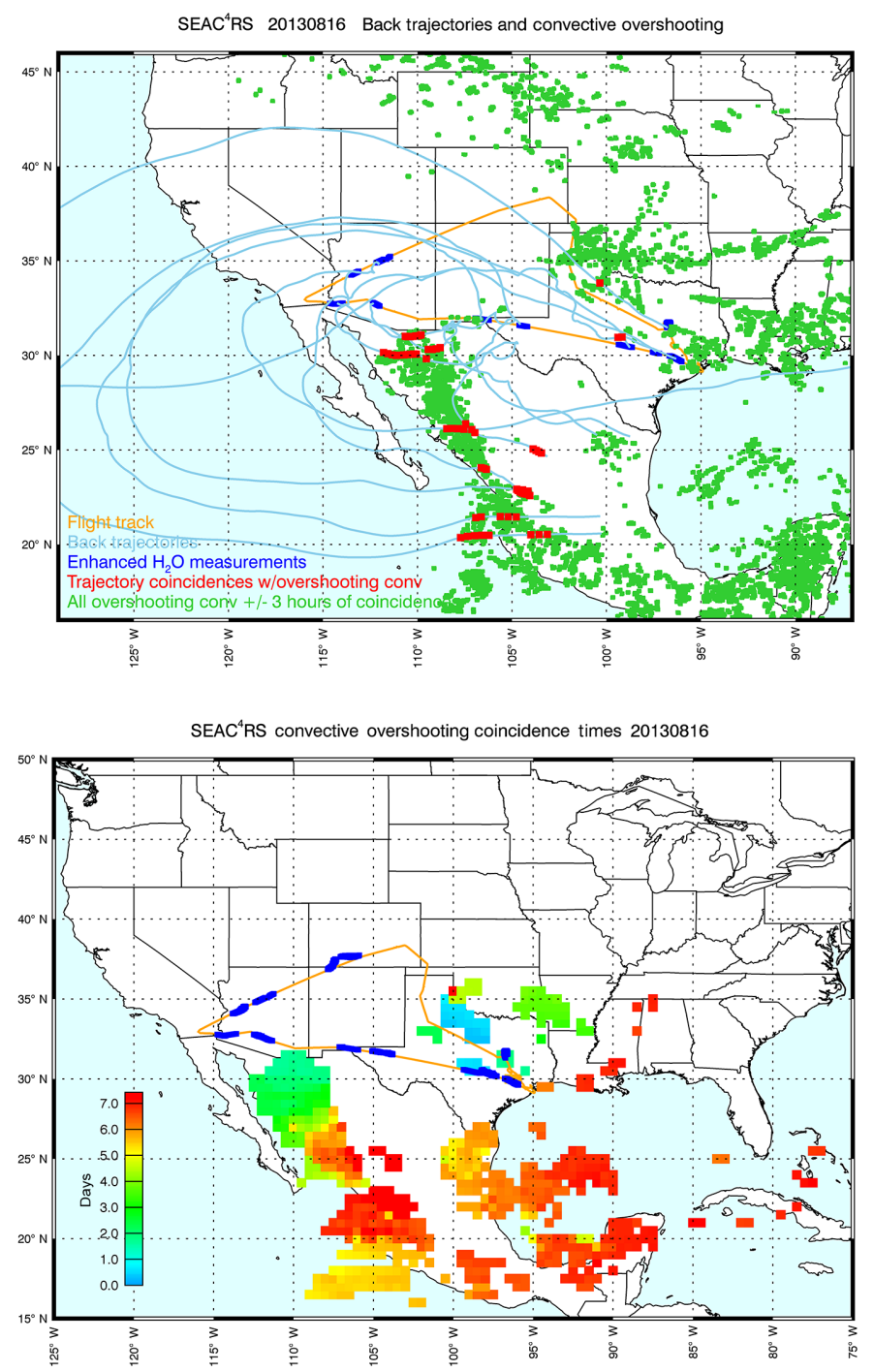

Figure 7. An analysis of the 16 August 2013 NASA ER-2 flight. (a) Vertical profiles of JLH Mark2 in situ $\mathrm{H}_{2} \mathrm{O}$; similar to Fig. 6a. (b) Back trajectories from the aircraft path; similar to Fig. 6b. (c) Altitude plot of back trajectories showing coincident overshooting (red) and all overshooting within $\pm 3 \mathrm{~h}$ (green); similar to Fig. 6c. (d) Days between OT and intercept by the aircraft; similar to Fig. 6d.

to 15 to $20 \mathrm{ppmv}$ at altitudes ranging from 16.0 to $17.5 \mathrm{~km}$ (Fig. 8a). The ER-2 aircraft intercepted highly enhanced stratospheric water from a mesoscale convective complex over the Upper Midwest, which had overshooting tops over northern Minnesota and northern Wisconsin (Toon et al., 2016), as shown in Fig. 8b. Figure 8c shows an abundance of OT above $17 \mathrm{~km}$ (green). Generally speaking, the OTs appear at higher altitudes in the northern CONUS and southern Canada than in the central CONUS. Figure $8 \mathrm{~d}$ shows that the air masses were sampled in situ by the ER-2 aircraft over Illinois and Indiana 1 to 2 days after the intense storm. As is a common theme for all these experiment days, a portion of the back trajectories also trace back to overshooting tops over the Sierra Madre Occidental 1 week prior.

\section{Conclusions}

In this paper, we have examined in situ measurements of stratospheric water taken by JLH Mark2 on the ER-2 aircraft during the SEAC ${ }^{4}$ RS field mission. With JLH Mark2 data, enhanced $\mathrm{H}_{2} \mathrm{O}$ above background mixing ratios was frequently encountered in the overworld stratosphere between 16 and $17.5 \mathrm{~km}$ of altitude. Back trajectories initialized at $1 \mathrm{~s}$ time stamps along the aircraft flight track at 16 to $17.5 \mathrm{~km}$ connect the sampled air parcels to convective OT within 7 days prior to the flight. The trajectory modeling indicates that the identified OTs are associated with larger storm systems over the South Central US (Fig. 6), deep convection over the Sierra Madre Occidental (Fig. 7) and deep convection over the Upper Midwest US and southern central Canada 


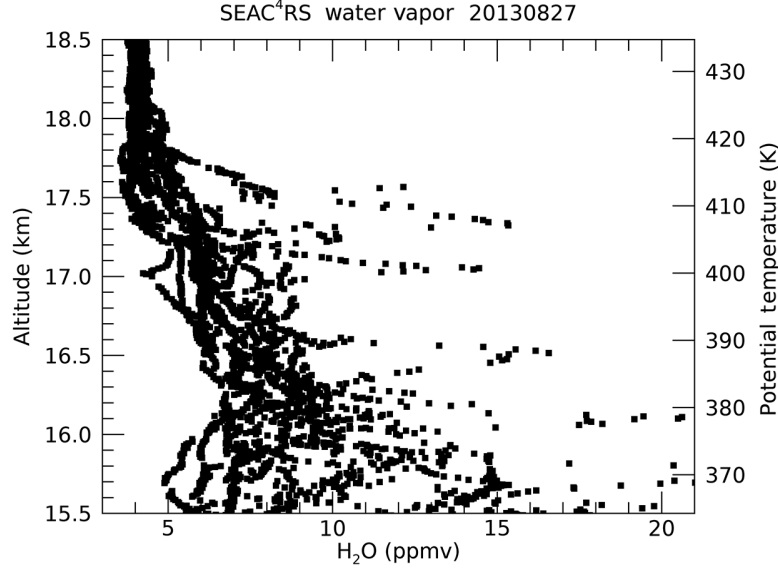

(a)

(b)
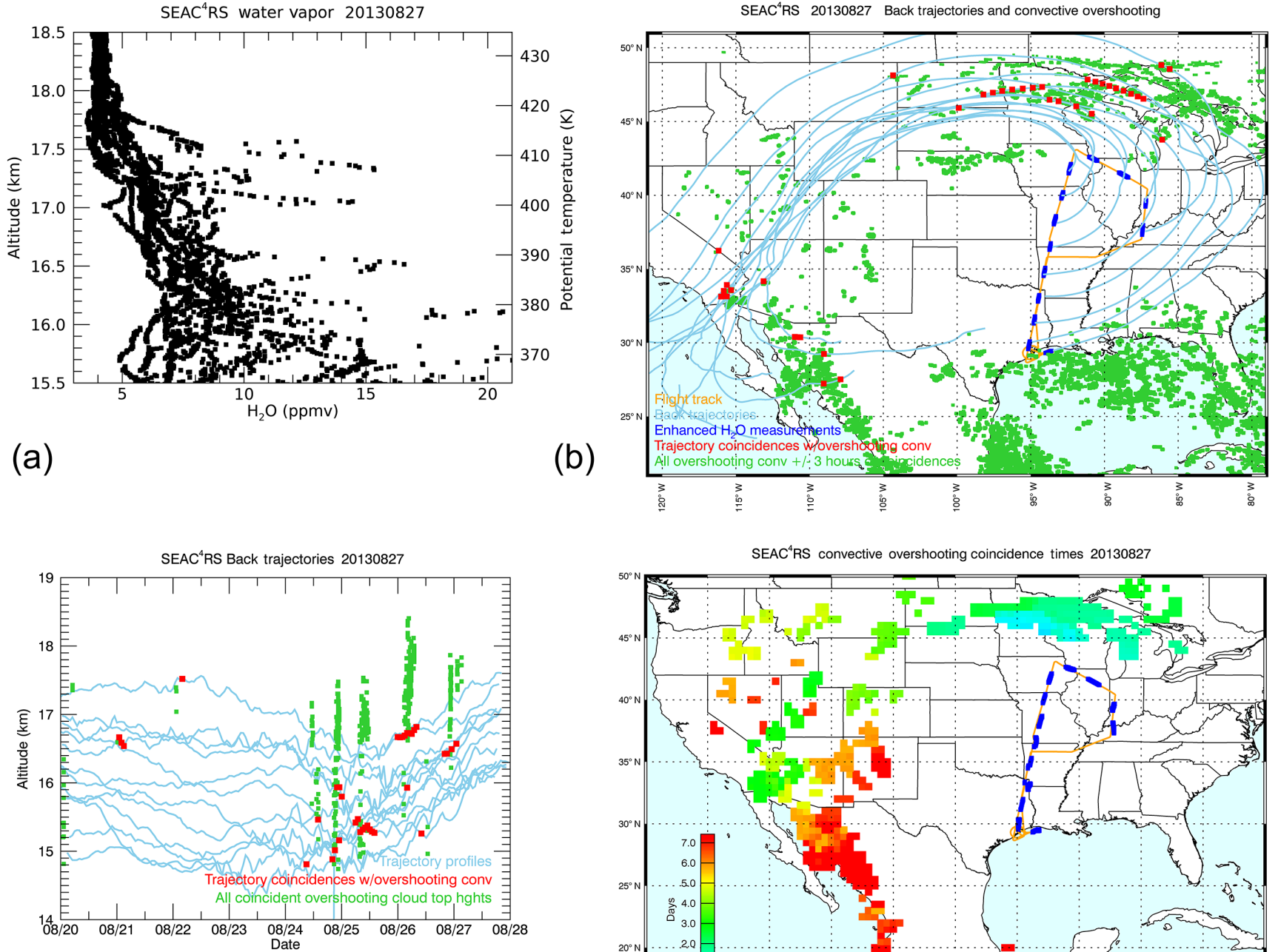

(c)

(d)

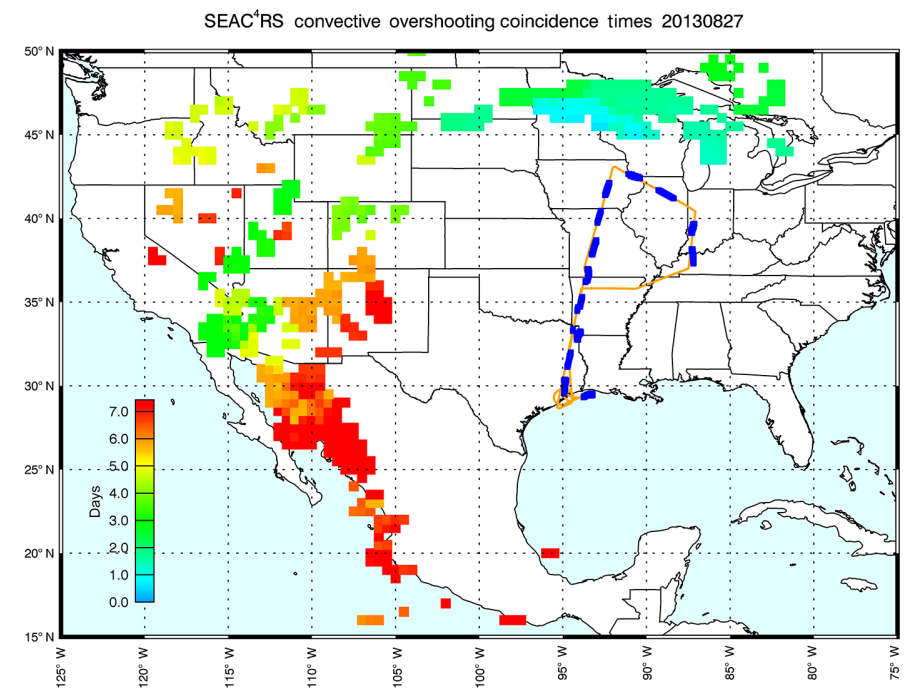

Figure 8. An analysis of the 27 August 2013 NASA ER-2 flight. (a) Vertical profiles of JLH Mark2 in situ $\mathrm{H}_{2} \mathrm{O}$; similar to Fig. 6a. (b) Back trajectories from the aircraft path; similar to Fig. 6b. (c) Altitude plot of back trajectories showing coincident overshooting (red) and all overshooting within \pm 3 h (green); similar to Fig. 6c. (d) Days between OT and intercept by the aircraft; similar to Fig. 6d.

(Fig. 8). For all the back trajectories in the three case studies, the fraction that connects to OT within the previous 7 days ranges from 30 to $70 \%$ (Fig. 9). The three aircraft flight dates analyzed in Fig. 9 have a higher fraction of enhanced water than the other flights. These three flights deliberately targeted air masses influenced by convection. For the CONUS in general, the fraction of air parcels at $370-420 \mathrm{~K}$ influenced by OT is much smaller.

The concentrations of enhanced water and the connection to OT suggests a mechanism for moistening the CONUS lower stratosphere: ice is irreversibly injected into the overworld stratosphere by the most intense convective tops. The temperatures of the CONUS lower stratosphere are sufficiently warm to sublimate the ice, producing water vapor mixing ratios elevated to $10 \mathrm{ppmv}$ or more above background levels. The summertime CONUS has a high frequency of thunderstorms with sufficient energy to transport ice to the upper troposphere (Koshak et al., 2015 and the references therein). On rare occasion, these storms have sufficient energy to loft ice through the tropopause and into the stratosphere. Further evidence of ice is provided by water isotopologues. Evaporation and condensation are fractionating processes for isotopologues, especially semiheavy water HDO relative to $\mathrm{H}_{2} \mathrm{O}$ (e.g., Craig, 1961; Dansgaard, 1964). Condensation preferentially concentrates the heavier HDO isotopologue, so lofted ice is relatively enriched in $\mathrm{HDO} / \mathrm{H}_{2} \mathrm{O}$ compared to the gas phase (e.g., Webster and Heymsfield, 2003 and the references therein). Ice sublimation is supported by the enriched $\mathrm{HDO} / \mathrm{H}_{2} \mathrm{O}$ isotopic signature observed by the ACE satellite over summertime North America 


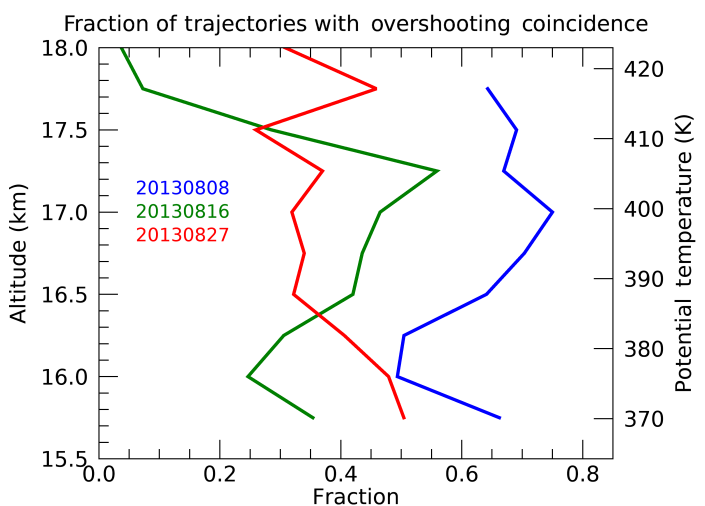

Figure 9. The fraction of back trajectories that intersected OTs during the 7 previous days for the three SEAC ${ }^{4} \mathrm{RS}$ flights on $8 \mathrm{Au}$ gust (blue), 16 August (green) and 27 August 2013 (red) shown in Figs. 6, 7 and 8, respectively.

(Randel et al., 2010). Cross-tropopause transport is a consequence of turbulent mixing at cloud top, possibly enhanced by the existence of breaking gravity waves often occurring near overshooting cloud tops (Wang, 2003). This study addresses a primary goal of the SEAC ${ }^{4} \mathrm{RS}$ field mission (Toon et al., 2016) and affirmatively answers the following scientific question: do deep convective cloud systems locally inject water vapor and other chemicals into the overworld stratosphere over the CONUS? This water is almost certainly injected in the ice phase and subsequently sublimated in the relatively warm stratosphere over CONUS, leading to irreversible hydration. From this study, we conclude that the depth of injection was typically 16 to $17.5 \mathrm{~km}$ of altitude for these particular summertime events.

Satellite retrievals of water vapor from Aura MLS provide a larger-scale context. The fraction of Aura MLS observations at $100 \mathrm{hPa}$ (approximately $17 \mathrm{~km}$ of altitude) with $\mathrm{H}_{2} \mathrm{O}$ greater than the 8 ppmv threshold is $0.9 \%$ for July-August 2013. In comparison, Schwartz et al. (2013) report that, for the 9-year record of 2004-2012, July and August had 1.4 and $3.2 \%$ of the observations exceed 8 ppmv, respectively. This reinforces the conclusion of Randel et al. (2015) that OTs play a minor role in the mid-latitude stratospheric water budget. At the $100 \mathrm{hPa}$ level in the lower stratosphere, the year 2013 was slightly drier than the average of 2004-2012 summers (Fig. 3). Despite the relatively dry conditions of summer 2013, there was sufficient enhanced water to be clearly observed in the Aura MLS retrievals (Figs. 3, 4 and 5). Limb measurements from Aura MLS come from a $\sim 200 \mathrm{~km}$ path through the atmosphere with $\sim 3 \mathrm{~km}$ of vertical resolution in the lower stratosphere (Livesey et al., 2016). The aircraft profiles of water vapor are very similar on ascent and descent (Fig. 5c), which allows us to estimate the horizontal length of these features as greater than $180 \mathrm{~km}$ and a vertical thickness of $\sim 0.5 \mathrm{~km}$. This size is sufficiently large that the MLS retrieval is sensitive to enhanced water, as shown in Fig. 5c.
In situ measurements probe air parcels on a small-scale that can be connected to OTs that inject ice and, to a lesser extent, trace gases into the stratosphere (e.g., Ray et al., 2004; Hanisco et al., 2007; Jost et al., 2004). In contrast, modeling studies tend to focus on large-scale processes. Dessler et al. (2002) and Corti et al. (2008) concluded that OTs are a significant source of water vapor in the mid-latitude lower stratosphere. In contrast, Randel et al. (2015) used Aura MLS observations to conclude that circulation plays a larger role than OT in controlling mid-latitude stratospheric water vapor in the NAM monsoon region. Our study shows clear evidence of observable perturbations to stratospheric water vapor on ER-2 aircraft flights that targeted convectively influenced air during SEAC ${ }^{4} \mathrm{RS}$. In future work, we plan a more detailed back trajectory analysis of air parcels over summertime North America to better understand the transport of ice and water in the lower stratosphere.

Data availability. Data discussed in this manuscript are publically available. The NASA aircraft data are available through the following digital object identifier (DOI): SEAC4RS doi:10.5067/Aircraft/SEAC4RS/Aerosol-TraceGas-Cloud.

Author contributions. Robert Herman prepared the manuscript with contributions from all coauthors and was responsible for all aspects of the JLH Mark2 as principal investigator. Eric Ray and Karen Rosenlof provided trajectory calculations and interpretation. Kristopher Bedka provided an overshooting top data product and interpretation. Robert Troy, Robert Stachnik and Keith Chin operated the JLH Mark2 instrument in the field and downloaded data. Robert Stachnik, Dejian Fu, Lance Christensen and Keith Chin also developed software components for the JLH Mark2 instrument. Michael Schwartz and William Read provided Aura MLS data and statistical analysis. T. Paul Bui and Jonathan Dean-Day measured pressure and temperature with the MMS instrument and provided data.

Competing interests. The authors declare that they have no conflict of interest.

Acknowledgements. We thank Jose Landeros and Dave Natzic for providing technical support in the laboratory and the field and the aircraft crew and flight planners for making these measurements possible. The JLH Mark2 team is supported by the NASA Upper Atmosphere Research Program and Radiation Sciences Program. Part of this research was performed at JPL, California Institute of Technology, under a contract with NASA.

Edited by: R. Müller

Reviewed by: two anonymous referees 


\section{References}

Adams, D. K. and Comrie, A. C.: The North American Monsoon, B. Amer. Meteorol. Soc., 78, 2197-2213, doi:10.1175/JCLI4071.1, 1997.

Anderson, J. G., Wilmouth, D. M., Smith, J. B., and Sayres, D. S.: UV Dosage Levels in Summer: Increased Risk of Ozone Loss from Convectively Injected Water Vapor, Science, 337, 835-839, 2012.

Bedka, K. M., Brunner, J., Dworak, R., Feltz, W., Otkin, J., and Greenwald, T.: Objective satellite-based overshooting top detection using infrared window channel brightness temperature gradients, J. Appl. Meteor. Climatol., 49, 181-202, 2010.

Bedka, K. M., Wang, C., Rogers, R., Carey, L., Feltz, W., and Kanak, J.: Examining deep convective cloud evolution using total lightning, WSR-88D, and GOES-14 super rapid scan datasets, Weather Forecast., 30, 571-590, doi:10.1175/WAF-D14-00062.1, 2015.

Boucher, O., Randall, D., Artaxo, P., Bretherton, C., Feingold, G., Forster, P., Kerminen, V.-M., Kondo, Y., Liao, H., Lohmann, U., Rasch, P., Satheesh, S. K., Sherwood, S., Stevens B., and Zhang, X. Y.: Clouds and Aerosols, in: Climate Change 2013: The Physical Science Basis, Contribution of Working Group I to the Fifth Assessment Report of the Intergovernmental Panel on Climate Change, edited by: Stocker, T. F., Qin, D., Plattner, G.-K., Tignor, M., Allen, S. K., Boschung, J., Nauels, A., Xia, Y., Bex, V., and Midgley, P. M., Cambridge University Press, Cambridge, United Kingdom and New York, NY, USA, 2013.

Brewer, A. W.: Evidence for a world circulation provided by the measurements of helium and water vapor distribution in the stratosphere, Q. J. Roy. Meteorol. Soc., 75, 351-63, 1949.

Corti, T., Luo, B. P., De Reus, M., Brunner, D., Cairo, F., Mahoney, M. J., Martucci, G., Matthey, R., Mitev, V., Dos Sntos, F. H., Schiller, C., Shur, G., Sitnikov, N. M., Spelten, N., Voessing, H. J., Borrmann, S., and Peter, T.: Unprecedented evidence for deep convection hydrating the tropical stratosphere, Geophys. Res. Lett., 35, L10810, doi:10.1029/2008GL033641, 2008.

Craig, H.: Isotopic Variations in Meteoric Waters, Science, 133, 1702-1703, doi:10.1126/science.133.3465.1702, 1961.

Dansgaard, W.: Stable isotopes in precipitation, Tellus, 16, 436-68, 1964.

Dessler, A. E., Hanisco, T. F., and Fueglistaler, S.: Effects of convective ice lofting on $\mathrm{H}_{2} \mathrm{O}$ and $\mathrm{HDO}$ in the tropical tropopause layer, J. Geophys. Res., 112, doi:10.1029/2007JD008609, 2007.

Fahey, D. W., Gao, R.-S., Möhler, O., Saathoff, H., Schiller, C., Ebert, V., Krämer, M., Peter, T., Amarouche, N., Avallone, L. M., Bauer, R., Bozóki, Z., Christensen, L. E., Davis, S. M., Durry, G., Dyroff, C., Herman, R. L., Hunsmann, S., Khaykin, S., Mackrodt, P., Meyer, J., Smith, J. B., Spelten, N., Troy, R. F., Vömel, H., Wagner, S., and Weinhold, F. G.: The AquaVIT-1 Intercomparison of Atmospheric Water Vapor Measurement Techniques, Atmos. Meas. Tech., 7, 3177-3213, doi:10.5194/amt-73177-2014, 2014.

Flury, T., Wu, D. L., and Read, W. G.: Variability in the speed of the Brewer-Dobson circulation as observed by Aura/MLS,Atmos. Chem. Phys., 13, 4563-4575, doi:10.5194/acp-13-4563-2013, 2013

Griffin, S. M., Velden, C. S., and Bedka, K. M.: A method for calculating the height of overshooting convective cloud tops using satellite-based IR imager and CloudSat cloud profiling radar observations, J. Appl. Meteorol. Climatol., 55, 479-491, doi:10.1175/JAMC-D-15-0170.1, 2016.

Hanisco, T. F., Moyer, E. J., Weinstock, E. M., St. Clair, J. M., Sayres, D. S., Smith, J. B., Lockwood, R., Anderson, J. G., Dessler, A. E., Keutsch, F. N., Spackman, J. R., Read, W. G., and Bui, T. P.: Observations of deep convective influence on stratospheric water vapor and its isotopic composition, Geophys. Res. Lett., 34, L04814, doi:10.1029/2006GL027899, 2007.

Holton, J. R., Haynes, P. H., Douglass, A. R., Rood, R. B., and Pfister, L.: Stratosphere-troposphere exchange, Rev. Geophys., 33, 403-439, 1995.

Homeyer, C. R., McAuliffe, J. D., and Bedka, K. M.: On the Development of Above-Anvil Cirrus Plumes in Extratropical Convection, J. Atmos. Sci., 74, 1617-1633, doi:10.1175/JAS-D-160269.1, 2017.

Jensen, E. J., Smith, J. B., Pfister, L., Pittman, J. V., Weinstock, E. M., Sayres, D. S., Herman, R. L., Troy, R. F., Rosenlof, K., Thompson, T. L., Fridlind, A. M., Hudson, P. K., Cziczo, D. J., Heymsfield, A. J., Schmitt, C., and Wilson, J. C.: Ice supersaturations exceeding $100 \%$ at the cold tropical tropopause: implications for cirrus formation and dehydration, Atmos. Chem. Phys., 5, 851-862, doi:10.5194/acp-5-851-2005, 2005.

Jensen, E. J., Diskin, G., Lawson, R. P., Lance, S., Bui, T. P., Hlavka, D., McGill, M., Pfister, L., Toon, O. B., and Gao, R., Ice nucleation and dehydration in the Tropical Tropopause Layer, P. Natl. Acad. Sci. USA, 110, 2041-2046, 2013.

Jost, H. J., Drdla, K., Stohl, A., Pfister, L., Loewenstein, M., Lopez, J. P., Hudson, P. K., Murphy, D. M., Cziczo, D. J., Fromm, M., Bui, T. P., Dean-Day, J., Gerbig, C., Mahoney, M. J., Richard, E. C., Spichtinger, N., Pittman, J. V., Weinstock, E. M., Wilson, J. C., and Xueref, I.: In-situ observations of mid-latitude forest fire plumes deep in the stratosphere, Geophys. Res. Lett., 31, L11101, doi:10.1029/2003GL019253, 2004.

Kirk-Davidoff, D. B., Hintsa, E. J., Anderson, J. G., and Keith, D. W.: The effect of climate change on ozone depletion through changes in stratospheric water vapour, Nature, 402, 399-401, doi:10.1038/46521, 1999.

Koshak, W. J., Cummins, K. L., Buechler, D. E., Vant-Hull B., Blakeslee, R. J., Williams, E. R., and H. S. Peterson: Variability of CONUS Lightning in 2003-12 and Associated Impacts, J. Appl. Meteorol. Climatol., 54, 15-41, doi:10.1175/JAMC-D-140072.1, 2015.

Livesey, N. J., Read, W. G., Wagner, P. A., Froidevaux, L., Lambert, A., Manney, G. L., Millan Valle, L. F., Pumphrey, H. C., Santee, M. L., Schwartz, M. J., Wang, S., Fuller, R. A., Jarnot, R. F., Knosp, B. W., and Martinez, E.: Earth Observing System (EOS) Aura Microwave Limb Sounder (MLS) Version 4.2x Level 2 data quality and description document, Tech. Rep. JPL D-33509 Rev. B, Version 4.2x-2.0, Jet Propulsion Laboratory, California Institute of Technology, Pasadena, CA, available online at: http://mls.jpl.nasa.gov/data/datadocs.php, last access: 9 May 2016.

Liu, C., Zipser, E. J., Cecil, D. J., Nesbitt, S. W., and Sherwood, S. J. Appl. Meteorol. Climatol. 47, 2712-2728, 2008.

Liu, N. and Liu, C.: Global distribution of deep convection reaching tropopause in 1 year GPM observations, J. Geophys. Res.Atmos., 121, doi:10.1002/2015JD024430, 2016. 
May, R. D.: Open-path, near-infrared tunable diode laser spectrometer for atmospheric measurements of $\mathrm{H}_{2} \mathrm{O}$, J. Geophys. Res., 103, 19161-19172, doi:10.1029/98jd01678, 1998.

Mullendore, G. L., Durran, D. R., and Holton, J. R.: Crosstropopause tracer transport in midlatitude convection, J. Geophys. Res., 110, D06113, doi:10.1029/2004JD005059, 2005.

Mullendore, G. L., Homann, A. J., Bevers, K., and Schumacher, C.: Radar reflectivity as a proxy for convective mass transport, J. Geophys. Res., 114, D16103, doi:10.1029/2008JD011431, 2009.

Randel, W. J., K. Zhang, and R. Fu: What controls stratospheric water vapor in the NH summer monsoon regions?, J. Geophys. Res., 120, 7988-8001, doi:10.1002/2015JD023622, 2015.

Ravishankara, A. R.: Water Vapor in the Lower Stratosphere, Science, 337, 809-810, doi:10.1126/science.1227004, 2012.

Ray, E. A., Rosenlof, K. H., Richard, E. C., Hudson, P. K., Cziczo, D. J., Loewenstein, M., Jost, H.-J., Lopez, J., Ridley, B., Weinheimer, A., Montzka, D., Knapp, D., Wofsy, S. C., Daube, B. C., Gerbig, C., Xueref, I., and Herman, R. L.: Evidence of the effect of summertime midlatitude convection on the subtropical lower stratosphere from CRYSTAL-FACE tracer measurements, J. Geophys. Res., 109, D18304, doi:10.1029/2004JD004655, 2004.

Roach, W. T.: On the nature of the summit areas of severe storms in Oklahoma, Q. J. Roy. Meteorol. Soc., 93, 318-336, 1967.

Rollins, A., Thornberry, T., Gao, R. S., Smith, J. B., Sayres, D. S., Sargent, M. R., Schiller, C., Krämer, M., Spelten, N., Hurst, D. F., Jordan, A. F., Hall, E. G., Vömel, H., Diskin, G. S., Podolske, J. R., Christensen, L. E., Rosenlof, K. H., Jensen, E. J., and Fahey, D. W.: Evaluation of UT/LS hygrometer accuracy by inter- comparison during the NASA MACPEX mission, J. Geophys. Res.Atmos., 119, 1915-1935, doi:10.1002/2013JD020817, 2014.

Saha, S., Moorthi, S., Wu, X., Wang, J., Nadiga, S., Tripp, P., Behringer, D., Hou, Y.-T., Chuang, H.-Y., Iredell, M., Ek, M., Meng, J., Yang, R., Mendez, M. P., Van den Dool, H., Zhang, Q., Wang, W., Chen, M., and Becker, E.: The NCEP Climate Forecast System Version 2, J. Climate, 27, 2185-2208, doi:10.1175/JCLI-D-12-00823.1, 2014.

Sargent, M. R., Smith, J. B., Sayres, D. S., and Anderson, J. G.: The roles of deep convection and extratropical mixing in the Tropical Tropopause Layer: An in situ measurement perspective, J. Geophys. Res., 119, 12355-12371, doi:10.1002/2014JD022157, 2014.

Sayres, D. S., Pfister, L., Hanisco, T. F., Moyer, E. J., Smith, J. B., St. Clair, J. M., O'Brien, A. S., Witinski, M. F., Legg, M., and Anderson, J. G.: Influence of convection on the water isotopic composition of the tropical tropopause layer and tropical stratosphere, J. Geophys. Res., 115, D00J20, doi:10.1029/2009JD013100, 2010.

Schwartz, M. J., Read, W. G., Santee, M. L., Livesey, N. J., Froidevaux, L., Lambert, A., and Manney, G. L.: Convectively injected water vapor in the North American summer lowermost stratosphere, Geophys. Res. Lett., 40, 2316-2321, doi:10.1002/grl.50421, 2013.
Scott, S. G., Bui, T. P., Chan, K. R., and Bowen, S. W.: The meteorological measurement system on the NASA ER-2 aircraft, J. Atmos. Ocean. Tech., 7, 525-540, 1990.

Shindell, D. T.: Climate and ozone response to increased stratospheric water vapor, Geophys. Res. Lett., 28, 1551-1554, 2001.

Smith, J. B., Sargent, M., Wilmouth, D., and Anderson, J. G.: Quantifying the Direct Convective Transport of Tropospheric Air to the Overworld Statosphere, Abstract A51O-0288, presented at 2015, Fall Meeting, AGU, San Francisco, CA, 14-18 December, 2015.

Solomon, D. L., Bowman, K. P., and Homeyer, C. R.: Tropopause-Penetrating Convection from Three-Dimensional Gridded NEXRAD Data, J. Appl. Meteorol. Climatol., 55, 465478, doi:10.1175/JAMC-D-15-0190.1, 2016.

Solomon, S., Rosenlof, K. H., Portmann, R. W., Daniel, J. S., Davis, S. M., Sanford, T. J., and Plattner, G.-K.: Contributions of Stratospheric Water Vapor to Decadal Changes in the Rate of Global Warming, Science, 327, 1219-1223, doi:10.1126/science.1182488, 2010.

Stohl, A., C. Forster, A. Frank, P. Seibert, and G. Wotawa: Technical note: The Lagrangian particle dispersion model FLEXPART version 6.2, Atmos. Chem. Phys., 5, 2461-2474, doi:10.5194/acp5-2461-2005, 2005.

Toon, O. B., Maring, H., Dibb, J., Ferrare, R., Jacob, D. J., Jensen, E. J., Luo, Z. J., Mace, G. G., Pan, L. L., Pfister, L., Rosenlof,K. H., Redemann, J., Reid, J. S., Singh, H. B., Thompson, A. M., Yokelson, R., Minnis, P., Chen, G., Jucks, K. W., and Pszenny, A.: Planning, implementation and scientific goals of the Studies of Emissions and Atmospheric Composition, Clouds and Climate Coupling by Regional Surveys (SEAC ${ }^{4} \mathrm{RS}$ ) field mission, J. Geophys. Res., 121, 4967-5009, doi:10.1002/2015JD024297, 2016.

Voemel, H., Oltmans, S. J., Johnson, B. J., Hasebe, F., Shiotani, M., Fujiwara, M., Nishi, N., Agama, M., Cornejo, J., Paredes, F., and Enriquez, H.: Balloon-borne observations of water vapor and ozone in the tropical upper troposphere and lower stratosphere, J. Geophys. Res., 107, ACL 8-1-ACL 8-16, doi:10.1029/2001JD000707, 2002.

Wang, P. K.: Moisture plumes above thunderstorm anvils and their contributions to cross-tropopause transport of water vapor in midlatitudes, J. Geophys. Res., 108, 4194, doi:10.1029/2002JD002581, 2003.

Webster, C. R. and Heymsfield, A. J.: Water Isotope Ratios D/H, ${ }^{18} \mathrm{O} /{ }^{16} \mathrm{O},{ }^{17} \mathrm{O} /{ }^{16} \mathrm{O}$ in and out of Clouds Map Dehydration Pathways, Science, 302, 1742, doi:10.1126/science.1089496, 2003. 